\title{
Avaliação da Acurácia Posicional Utilizando os Métodos de Feição Linear: Pontos Finais, Pontos Intermediários, Ponto Gerado, Influência do Vértice, Normalização do Buffer Duplo e Fator de Fuzziness
}

\section{Positional Accuracy in Cartographic Data Using Linear Features Methods: Final Points, Intermediate Points, Generated Point, Vertex Influence, Double Buffer Normalization and Fuzziness Factor}

Juliette Zanetti ${ }^{1}$, Afonso de Paula dos Santos ${ }^{2}$, Nilcilene das Graças Medeiros ${ }^{3}$ e Julio Cesar de Oliveira ${ }^{4}$

1 Universidade Federal de Viçosa, Departamento de Engenharia Civil, Viçosa, Brasil. juliette.zanetti@ufv.br. ORCID: https://orcid.org/0000-0001-6816-4587

2 Universidade Federal de Viçosa, Departamento de Engenharia Civil, Viçosa, Brasil. afonso.santos@ufv.br. ORCID: http://orcid.org/0000-0001-7248-4524

3 Universidade Federal de Viçosa, Departamento de Engenharia Civil Viçosa, Brasil. nilcilene.medeiros@ufv.br. ORCID: http://orcid.org/0000-0003-0839-3729

4 Universidade Federal de Viçosa, Departamento de Engenharia Civil, Viçosa, Brasil. oliveirajc@ufv.br.

ORCID: http://orcid.org/0000-0003-0894-5597

Resumo: Nos últimos anos, o uso de feições lineares tem sido frequentemente investigado no controle de qualidade cartográfica, sendo que diversos métodos foram propostos para avaliação da acurácia posicional. Neste sentido, o presente trabalho teve como objetivo atrelar as tolerâncias definidas no Decreto $n^{\circ} 89.817$ e à Especificação Técnica de Controle de Qualidade de Dados Espaciais (ET-CQDG) nos métodos de feições lineares: Pontos finais, Pontos Intermediários, Ponto Gerado e em uma adaptação proposta ao método Fator Fuzziness. Ao final, tais métodos foram comparados com os métodos de feições lineares já aplicados no Brasil que são: Influência do Vértice e Normalização do Buffer Duplo. Para tanto, foi avaliada a acurácia posicional planimétrica de um ortomosaico no município de Viçosa-MG, onde os resultados obtidos mostraram que os métodos do Pontos Finais, Influência de Vértice, Fator Fuzziness e o método de normalização do Buffer Duplo obtiveram classificação planimétrica Classe A para a escala de 1:1.000. Já os métodos Pontos Intermediários e Ponto Gerado apresentaram Classe B na escala 1:1.000.

Palavras-chave: Discrepância Posicional. Feições Lineares. Controle de Qualidade Cartográfica. Similaridade.

\begin{abstract}
In recent years, the use of linear features has been frequently investigated in cartography quality control, and several methods have been proposed to assess positional accuracy. In this sense, the present work aimed to link the tolerances defined in Decree ${ }^{\circ}$ 89.817, and the Technical Specification for Quality Control of Spatial Data (ETCQDG) in the methods of linear features: End points, Intermediate Points, Generated Point and in a proposed adaptation to the Fuzziness Factor method. In the end, such methods were compared with the linear feature methods already applied in Brazil, which are: Influence of the Vertex and Normalization of the Double Buffer. For this purpose, the planimetric positional accuracy of an orthomosaic in the municipality of Viçosa-MG was evaluated, where the results obtained showed that the methods, Final Points, Vertex Influence, Factor Fuzziness and the Buffer Double normalization method obtained classification Class A planimetric scale for the 1: 1,000 scale. The Intermediate Points and Generated Point methods, on the other hand, presented Class B in the 1: 1,000 scale.
\end{abstract}

Keywords: Positional discrepancy. Linear Features. Cartographic Quality Control. Similarity.

\section{INTRODUÇÃO}

Na cartografia, necessita-se modelar o mundo real de modo que o mesmo possa ser representado o 
mais fidedignamente possível através de dados espaciais. Goodchild (2010) ressalta a importância do controle de qualidade ao investigar dados espaciais de modo a garantir e especificar a qualidade e acurácia dos mesmos, explicitando discrepâncias, omissões e incertezas, bem como definindo sua finalidade. Assim, quanto maior o nível de controle de qualidade em uma base de dados espaciais, provavelmente, maior será o nível de acerto na tomada de decisões utilizando estes dados (SANTOS et al., 2016). Segundo Tveite e Langaas (1995), a disponibilidade de informações de qualidade é um pré-requisito para a utilização de conjuntos de dados geográficos. No uso de qualquer material cartográfico, recomenda-se o conhecimento prévio de sua acurácia, caso contrário pode ser gerados resultados que fiquem abaixo do esperado (BURITY, 1999). Na área de Cartografia, a avaliação da qualidade de dados espaciais deve considerar diversos elementos. A norma ISO 19157:2013 aborda seis elementos de qualidade de dados espaciais: completude, acurácia posicional, acurácia temática, acurácia temporal, consistência lógica e usabilidade. Segundo Ariza e Atkinson (2008), a acurácia posicional é um dos elementos mais focados nos institutos de mapeamentos.

A acurácia posicional refere-se a quão próxima a posição de um dado espacial está em relação à sua realidade no terreno (ARIZA, 2002; NOGUEIRA JÚNIOR, 2003). Para avaliar a acurácia posicional de dados espaciais, utiliza-se a comparação entre as suas informações geométricas com as observadas no campo ou um produto com maior acurácia, obtendo-se, assim, um conjunto de discrepâncias posicionais. Estas discrepâncias são utilizadas para a classificação da acurácia posicional do dado espacial de acordo com alguma norma adotada no país.

$\mathrm{Na}$ avaliação da acurácia posicional em dados cartográficos podem-se utilizar as primitivas gráficas: ponto, linha e polígono. Nos trabalhos de Giordano e Veregin (1994), Tveite e Langaas (1995), Ariza (2002), Nogueira Júnior (2003), Nero (2005), Ariza e Atkinson (2008), Santos (2010), Pereira e Nero (2012), Silva e Schuler (2015), entre outros, são observadas metodologias fundamentadas na comparação entre pontos homólogos pertencentes a diferentes bases cartográficas. Diversos países, têm suas Normas e Leis fundamentadas em feições pontuais, como observado nos trabalhos de Ariza (2002), Nogueira Júnior (2003), Nero (2005), Santos (2010), Pereira e Nero (2012), entre outros.

Já nas últimas décadas, métodos de avaliação posicional que utilizam feições lineares tem sido aplicados em pesquisas de Sistemas de Informações Geográficas (SIG), direcionando um grande esforço da comunidade científica para a compreensão do tema e desenvolvimento de diferentes métodos de avaliação (TONG et al., 2013).

Segundo Santos et al. (2015), os métodos de avaliação da acurácia posicional com o uso de feições lineares consideram a comparação entre linhas homólogas dos dados de referência em relação aos dados de teste analisando aspectos como: razão entre comprimentos e quantidade de vértices, angularidade, razão de segmentos curvilíneos, distância entre os vértices, percentual de inclusão em uma área de influência, entre outros. Entre os métodos existentes que utilizam feições lineares, podem-se citar: Banda Épsilon, Buffer Simples, Buffer Duplo, Banda-G; Influência do Vértice, Distância de Hausdorff, Modelo de Erro Estatístico de Simulação, Aproximações por Spline, Retângulo Envolvente, Completude, RMS modificado, Ponto Gerado, Pontos finais em feições lineares, Pontos intermediários em feições lineares, Fator Fuzziness (MASRY; GAUTHIER; LEE, 1980; LUGNANI, 1980; BLAKEMORE, 1984; LUGNANI, 1986; TVEITE; LANGAAS, 1995; GOODCHILD; HUNTER, 1997; HEIPKE et al., 1997; FERREIRA; CINTRA, 1999; TVEITE; LANGAAS, 1999; SHI; LIU, 2000; GALO; ALUIR; FRANCE, 2001; DAL POZ, GALO; FERREIRA, 2001; ARIZA, 2002; RAMIREZ; ALI, 2003; MOZAS; ARIZA, 2010; 2011; TONG et al., 2013).

Segundo Mozas e Ariza (2011), os primeiros estudos analisando as discrepâncias entre feições lineares foram realizados para obter discrepâncias posicionais derivados do processo de simplificação. McMaster (1986) descreve um conjunto de avaliação para comparar a geometria de uma linha antes e depois do processo de simplificação, assim como apresenta algumas medidas comparativas para analisar a discrepância entre a feição de linha simplificada e a original. A ideia básica por trás da avaliação posicional que utilizam feições lineares é encontrar uma maneira de medir a similaridade entre duas representações de linha, uma vez que as duas linhas representam basicamente a mesma característica (RAMIREZ e ALI, 2003). Mozas (2007) menciona em seu trabalho que a aplicação desses métodos de verificação de acurácia posicional faz sentido hoje graças aos avanços tecnológicos em geral e as técnicas de obtenção dos elementos de referência linear, que podem ser obtidos de forma mais rápida, usando tecnologia de Sistema Global de Navegação por Satélite 
(GNSS), algo que em algumas décadas atrás era impensável.

Neste contexto, o objetivo do presente trabalho é propor metodologicamente vincular as tolerâncias definidas no Decreto n 89.817 de 1984 / ET-CQDG aos métodos de feições lineares Fator Fuzziness, Pontos finais, Pontos Intermediários e Ponto Gerado para avaliação da acurácia posicional planimétrica. Após, é realizada a comparação dos resultados obtidos com os métodos de Influência do Vértice e Normalização do Buffer Duplo. Para tal, será avaliada a acurácia posicional planimétrica de um ortomosaico, na escala 1:1.000, no município de Viçosa-MG. Vale ressaltar que este artigo sugere uma adaptação ao método Fator Fuzziness.

\section{MÉTODOS DE AVALIAÇÃO DA ACURÁCIA POSICIONAL QUE UTILIZAM FEIÇÕES LINEARES}

$\mathrm{Na}$ avaliação da acurácia posicional é realizada com base nas tolerâncias denominadas de Padrão de Exatidão Cartográfica (PEC) e Erro Padrão (EP). A ET-CQDG define a metodologia utilizada ao se avaliar a acurácia posicional em produtos cartográficos, bem como emprega uma classe para produtos digitais com tolerâncias mais restritivas que o Decreto ${ }^{\circ}$ 89.817. O principal objetivo desta especificação técnica é fornecer uma forma padronizada para avaliar a qualidade dos produtos de conjuntos de dados espaciais integrantes do Sistema Cartográfico Nacional (SCN) do Brasil (DSG, 2016). Utilizando ET-CQDG, devem-se atender dois critérios para avaliar a acurácia posicional: (i) $90 \%$ dos pontos bem definidos, quando testados no terreno, não deverão apresentar discrepâncias superiores a ET-CQDG, para a classe e escala testadas; e (ii) A raiz do valor quadrático médio (RMS) da amostra de discrepâncias seja igual ou inferior ao valor do EP, estabelecido para a escala e classe testadas.

Se as duas condições forem verdadeiras, o produto em análise é aprovado para a escala e classe testadas, mas se alguma das duas condições for falsa, o resultado será reprovado. A Tabela 1 apresenta as tolerâncias utilizadas na avaliação da acurácia posicional utilizando o padrão descrito no Decreto 89.817/ ETCQDG.

Tabela 1 - Tolerâncias utilizadas para avaliação da acurácia posicional utilizando Decreto 89.817 aliado à ET-CQDG.

\begin{tabular}{c|c|c}
\hline \multirow{2}{*}{ Classe } & \multicolumn{2}{|c}{ Planimetria } \\
\cline { 2 - 3 } & PEC-PCD $(\mathbf{m m})$ & EP $(\mathbf{m m})$ \\
\hline A & $0,28 *$ escala & $0,17^{*}$ escala \\
\hline B & $0,50 *$ escala & $0,30^{*}$ escala \\
\hline C & $0,80^{*}$ escala & $0,50^{*}$ escala \\
\hline D & $1,0^{*}$ escala & $0,60^{*}$ escala \\
\hline
\end{tabular}

Fonte: Os autores (2021).

Um dos aspectos importantes é que a avaliação da acurácia posicional de produtos cartográficos geralmente é realizada por meio de técnicas que se baseiam na verificação de feições pontuais homólogas do produto avaliado e o dado de referência. No entanto, existem casos em que o número de pontos não é suficiente, e/ou sua distribuição não é abrangente em toda a extensão geográfica a ser avaliada (SANTOS, 2010). Estes problemas mostram que, embora os modelos usando pontos sejam conhecidos e tenham sido testados, é recomendável estudar alternativas complementares como a utilização de Feições Lineares. A seguir serão apresentados alguns métodos de feições lineares, sendo eles Pontos Extremos em feições lineares, Pontos intermediários em feições lineares, Ponto Gerado, Fator Fuzziness, Influência do Vértice e Normalização do Buffer duplo, que foram utilizados neste trabalho.

\subsection{Pontos Extremos em feições lineares}

Segundo Tveite e Langaas (1995), os pontos das extremidades das feições lineares podem ser usados para fornecer uma medida de acurácia. Os pontos extremos de tais feições podem ser identificados nos cruzamentos de vias, em uma rede rodoviária, nos rios, entre outros. Após identificar os pontos extremos correspondentes no conjunto de dados da linha de referência $\left(L_{R}-\right.$ linha azul) e no conjunto de dados testado $\left(\mathrm{L}_{\mathrm{T}}\right.$ - linha vermelha), deve-se avaliar a acurácia dos pontos extremos com base nas discrepâncias posicionais 
observadas. Para a aplicação do método dos Pontos Extremos, utilizando como base as tolerâncias do Decreto $\mathrm{n}^{\circ} 89.817$, propõem-se as seguintes etapas:

a) Selecionar uma amostra contendo $n$ linhas homólogas de teste $\left(L_{T}\right)$ e de referência $\left(L_{R}\right)$;

b) Identificar os pontos extremos (finais e iniciais) das linhas teste $\left(L_{T}\right)$ e de referência $\left(L_{R}\right)$;

c) Calcular as discrepâncias posicionais $\left(D_{2 d}\right)$ conforme as Eq. (1), (2) e (3);

$$
\begin{gathered}
D_{x}=X_{T}-X_{R} \\
D_{y}=Y_{T}-Y_{R} \\
D_{2 d}=\sqrt{D_{x}^{2}+D_{y}^{2}}
\end{gathered}
$$

sendo:

$X_{T}$ : Abscissa da linha teste;

$X_{R}$ : Abscissa da linha de referência;

$Y_{T}$ : Ordenada da linha teste;

$Y_{R}$ : Ordenada da linha de referência;

$D_{x}$ : Discrepância em X;

$D_{y}$ : Discrepância em Y;

d) Calcular o RMS das discrepâncias dos pontos finais de cada linha, conforme as Eq. (4);

$$
R M S=\sqrt{\frac{\sum\left(D_{2 d}\right)^{2}}{n}}
$$

e) Para a aplicação do Decreto ${ }^{\circ} 89.817$ deve-se verificar o atendimento de duas condições em cada linha: (i) pelo menos $90 \%$ das discrepâncias de em análise devem apresentar valor menor ou igual ao valor do PEC, para a classe e escala utilizada; (ii) o RMS do conjunto de discrepância deve ser menor ou igual ao valor de EP, para a classe e escala utilizada;

f) Para análise do produto como um todo, $90 \%$ das linhas testadas devem atender ambas as condições do item 5. Sendo satisfeito essa análise o produto é aprovado na classe e escala testada, caso contrário o produto é reprovado. Assim deve-se retornar ao item e) e testar uma classe inferior. Caso não haja classificação nas classes disponíveis, deve-se testar uma escala menor.

Uma limitação deste método consiste em considerar somente a discrepância posicional nos pontos extremos das linhas, sem levar em conta seu comportamento geral. Por exemplo, na Figura 1, observa-se que o mesmo vetor de discrepância entre os pontos finais das linhas (discrepância posicional em $\mathrm{B}=0 \mathrm{e}$ discrepância posicional em $\mathrm{A} \neq 0$ ) ocorre em ambos os exemplos ilustrados, no entanto, verifica-se que as linhas se comportam de maneira diferentes. Dessa forma nota-se que, apesar de realizar as análises em feições lineares, este método se aproxima do método de feições pontuais, similar ao expresso no Decreto 89.817 aliado à ET-CQDG. 
Figura 1 - Análise do comportamento da linha de referência $L_{R}$ e da linha teste $L_{T}$. Discrepância posicional em B $=0$ e discrepância posicional em $\mathrm{A} \neq 0$.

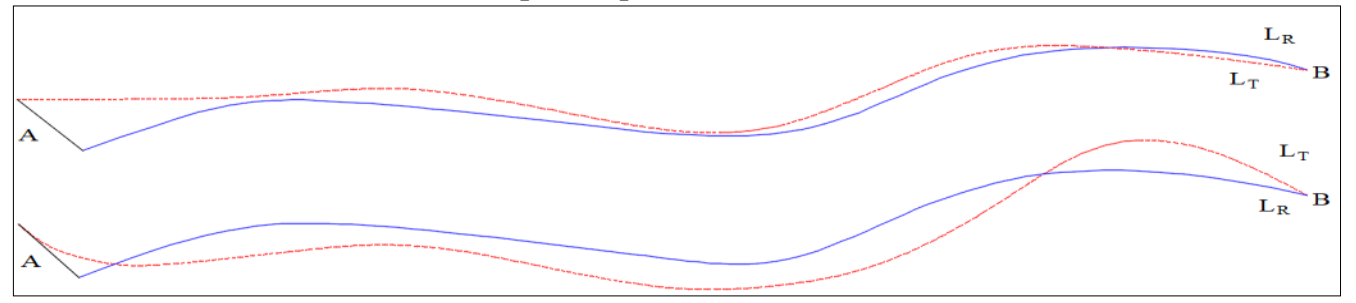

Fonte: Os autores (2021).

\subsection{Pontos Intermediários em feições lineares}

Para Tveite e Langaas (1995) outra forma de determinar a acurácia posicional de uma linha teste $\left(L_{T}\right)$ em comparação com uma linha de referência $\left(L_{R}\right)$ seria percorrer a linha teste em intervalos regulares (espaçamento $\varepsilon$, por exemplo), extraindo pontos de amostra. Com base em cada um desses pontos faz-se uma busca pelo ponto mais próximo da linha de referência, obtendo então a discrepância posicional. Assim, com posse nos pontos obtidos na linha teste e na linha de referência, uma medida geral da acurácia pode ser calculada estatisticamente. Kagawa et al. (1999) descrevem este método como método de correspondência dos pontos.

Segundo Tveite e Langaas (1995), o método deve ser aplicado em uma amostra de linhas que possuem correspondência no conjunto de dados de referência, obtendo uma medida da acurácia posicional no conjunto de dados.

Para a aplicação do método do Ponto Intermediário, utilizando como base as tolerâncias do Decreto ${ }^{\circ}$ 89.817, propõem-se as seguintes etapas:

a) Selecionar uma amostra de n linhas homólogas de teste $\left(L_{T}\right)$ e de referência $\left(L_{R}\right)$;

b) Criar pontos de amostra na linha teste $\left(\mathrm{L}_{\mathrm{T}}\right)$ em intervalos regulares (espaçamento $\varepsilon$, por exemplo), sendo esse tipo de dado, formado por números inteiros (variável discreta). Utiliza-se como tamanho do espaçamento $\varepsilon$, o valor do erro de graficismo (eg) para a escala utilizada no processo de avaliação;

c) Com base em cada um desses pontos, faz-se uma busca pelo ponto mais próximo da linha de referência $\left(L_{R}\right)$;

d) De posse de coordenadas na linha teste $\left(\mathrm{L}_{T}\right)$ e na linha de referência $\left(\mathrm{L}_{\mathrm{R}}\right)$, deve-se calcular a discrepância posicional baseado nas Eq. (1), (2) e (3);

e) Calcular o RMS das discrepâncias dos pontos intermediários de cada linha baseado na Eq. (4);

f) Para a aplicação do Decreto $n^{\circ} 89.817$, deve-se verificar se pelo menos $90 \%$ do conjunto de discrepâncias de cada linha em análise apresentam valor menor ou igual ao valor do PEC, bem como o RMS de cada linha ser menor ou igual ao valor de EP, para a classe e escala utilizada;

g) Para análise do produto como um todo, $90 \%$ das linhas testadas devem atender ambas as condições do item 6 . Sendo satisfeito essa análise o produto é aprovado na classe e escala testada, caso contrário o produto é reprovado. Assim deve-se retornar ao item f) e testar uma classe inferior. Caso não haja classificação nas classes disponíveis, deve-se testar uma escala menor.

Verifica-se que o espaçamento $\varepsilon$ irá influenciar diretamente no resultado das discrepâncias. Por exemplo, a Figura 2 ilustra a influência do valor do espaçamento $\varepsilon$ para identificação dos pontos a serem analisados entre as linhas teste $\left(\mathrm{L}_{\mathrm{T}}\right)$ e de referência $\left(\mathrm{L}_{\mathrm{R}}\right)$. 
Figura 2 - Análise do comportamento da linha de referência $L_{R}$ e da linha teste $L_{T}$ com diferentes espaçamentos ( $\varepsilon$ e $\left.\varepsilon^{\prime}\right)$ adotados.

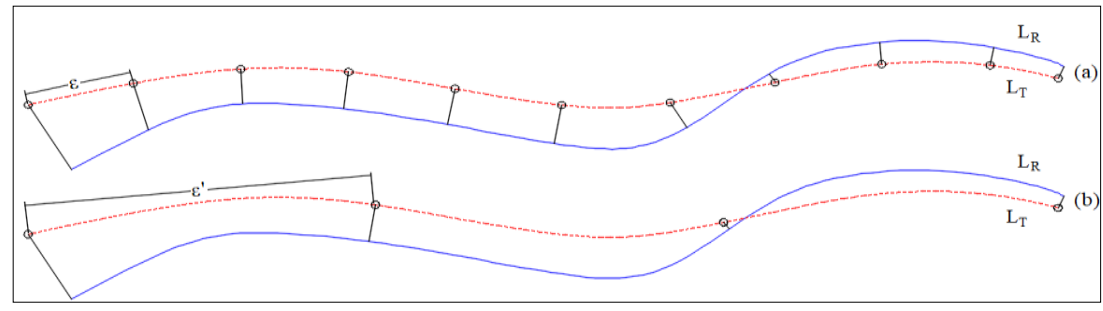

Fonte: Os autores (2021).

Outra característica que influenciará neste método ocorre quando os comprimentos das linhas de referência e teste forem diferentes. Um exemplo pode ser verificado na Figura 3 onde vários pontos finais na linha teste $\left(L_{T}\right)$ terão o mesmo ponto de correspondência na linha de referência $\left(L_{R}\right)$.

Figura 3 - Análise do comportamento da linha de referência $L_{R}$ e da linha teste $L_{T}$ com diferentes comprimentos.

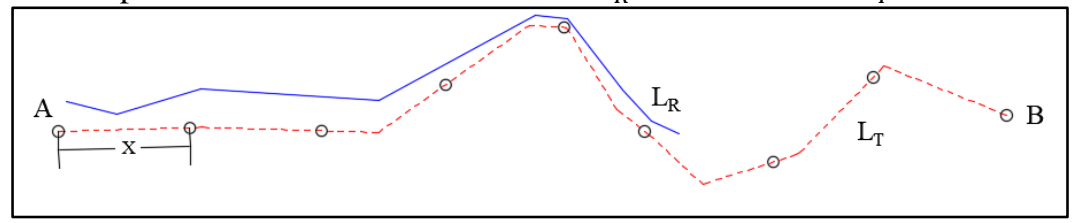

Fonte: Os autores (2021).

\subsection{Ponto Gerado}

Masry et al. (1980) propôs o método do Ponto gerado, conhecido também por Schmidley (1996) como método de distorção, onde compara pontos gerados na linha teste $\left(\mathrm{L}_{\mathrm{T}}\right)$ com pontos gerados na linha de referência $\left(L_{R}\right)$. Este método difere do método Pontos Intermediários, pois define espaçamentos ao longo das linhas teste e referência, enquanto o anterior define espaçamentos apenas na linha de teste.

Segundo Galo et al. (2001), o número de pontos normalmente é diferente entre duas digitalizações e/ou entre uma digitalização e o levantamento de campo já que o espaçamento entre os pontos consecutivos não é mantido ou definido de forma constante. Uma alternativa é gerar um conjunto de pontos na linha teste e na linha de referência como mesmo espaçamento. Admitindo que os pontos iniciais em cada uma das feições sejam homólogos, pode-se simplesmente comparar as distâncias entre os pontos gerados. Vieira e Mather (2005) aplicaram o método do Ponto Gerado para avaliação posicional em imagens de satélites aplicando o teste do Qui-quadrado aliado com as tolerâncias do Decreto 89.817.

Para a aplicação do método do Ponto Gerado, utilizando o padrão de acurácia posicional brasileiro, propõem-se as seguintes etapas:

h) Selecionar uma amostra de n linhas homólogas de teste $\left(L_{T}\right)$ e de referência $\left(L_{R}\right)$;

i) Criar pontos de amostra na linha teste $\left(L_{T}\right)$ e na linha de referência $\left(L_{R}\right)$ em intervalos regulares (espaçamento $\varepsilon$, por exemplo), sendo esse tipo de dado, formado por números inteiros (variável discreta). Utiliza-se como tamanho do espaçamento $\varepsilon$, o valor do erro de graficismo (eg) para a escala utilizada no processo de avaliação;

j) De posse de coordenadas na linha teste $\left(\mathrm{L}_{T}\right)$ e na linha de referência $\left(\mathrm{L}_{\mathrm{R}}\right)$, deve-se calcular a discrepância posicional baseado nas Eq. (1), (2) e (3);

k) Calcular o RMS das discrepâncias dos pontos gerados de cada linha baseado na Eq. (4);

1) Para a aplicação do Decreto ${ }^{\circ} 89.817$, deve-se verificar se pelo menos $90 \%$ do conjunto de discrepâncias de cada linha em análise apresentam valor menor ou igual ao valor do PEC, bem como o RMS de cada linha ser menor ou igual ao valor de EP, para a classe e escala utilizada;

m) Para análise do produto como um todo, $90 \%$ das linhas testadas devem atender ambas as condições do item e). Sendo satisfeito essa análise o produto é aprovado na classe e escala testada, caso contrário o produto é reprovado. Assim deve-se retornar ao item 5 e testar em outra classe e escala inferior.

No método do ponto gerado há a necessidade de se conhecer uma correspondência inicial entre as 
feições envolvidas. Além disso é possível que ocorra um acúmulo de erros quando ambas as feições apresentam diferenças significativas em suas formas (LUGNANI, 1986). Como representado na Figura 4, partindo do extremo A com espaçamento de $X$, por exemplo tanto na linha de referência $\left(L_{R}\right)$ quanto na linha teste $\left(L_{T}\right)$, nota-se que devido as linhas não terem o mesmo comprimento chega-se na extremidade $\mathrm{B}$ faltando correspondência no último ponto da linha de referência $\left(L_{R}\right)$.

Figura 4 - Método do Ponto Gerado com as extremidades das feições lineares desordenadas.

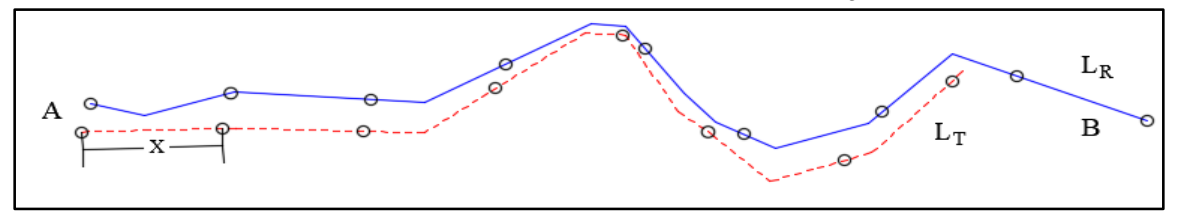

Fonte: Os autores (2021).

\subsection{Fator Fuzziness (adaptação)}

Para Ramirez e Ali (2003), Fuzziness é o fator relacionado à definição e identificação dos pontos extremos das feições lineares a serem comparados. Sempre que duas representações de características lineares do mesmo objeto são extraídas de diferentes fontes de dados, existe um alto grau de probabilidade de que possam ser diferentes, sendo fundamental considerar e avaliar sua discrepância.

Assim, calcula-se a discrepância dos pontos extremos da feição linear de teste em relação ao ponto homólogo da feição linear de referência. A Figura 5 ilustra a ideia do Fator Fuzziness, representando a variabilidade dos pontos extremos do segmento de linha menos acurada (representada com o círculo de cor vermelha) em relação ao segmento de linha mais acurada (representada com o círculo de cor azul).

O tamanho dos círculos reflete a variabilidade das discrepâncias. Observa-se, pela Figura 5 que as distâncias que separam os pontos extremos das duas linhas, representadas por R e S, são usadas para esboçar os raios dos círculos. Em seguida o Fator Fuzziness é calculado através do cálculo referente a área comum (área de sobreposição) dos dois círculos em razão da área do círculo correspondente (RAMIREZ e ALI, 2003).

Figura 5 - Análise da discrepância pelo método do Fator Fuzziness com separação dos vértices de R e S.

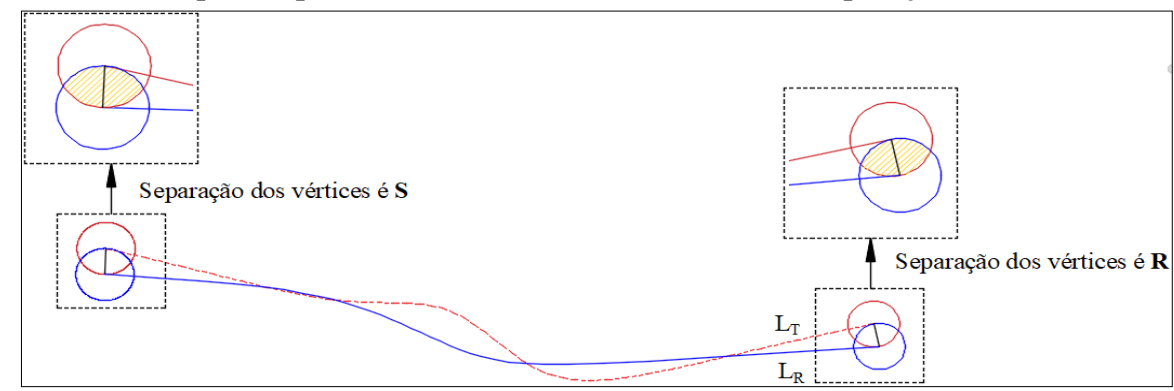

Fonte: Os autores (2021).

Para a aplicação do Fator Fuzziness, utilizando o padrão de acurácia posicional brasileiro, propõem-se as seguintes etapas:

n) Selecionar uma amostra de n linhas homólogas de teste $\left(L_{T}\right)$ e de referência $\left(L_{R}\right)$;

o) Analisar as distâncias entre os extremos das linhas;

p) Usar o valor das distâncias entre os extremos das linhas para criar círculos em torno dos vértices das linhas;

q) Calcular a discrepância posicional a partir da proporção da área comum (área de sobreposição) dos círculos em relação a área do círculo correspondente, baseado na Eq. (5);

$$
F F=\frac{\text { área em comum }}{\pi r^{2}}
$$

r) Calcular o RMS das discrepâncias posicionais calculadas na etapa anterior;

s) Para a aplicação do Decreto n ${ }^{\circ} 89.817$, deve-se verificar se pelo menos $90 \%$ do conjunto de discrepâncias de cada linha em análise apresentam valor menor ou igual ao valor do PEC, bem como 
o RMS de cada linha ser menor ou igual ao valor de EP, para a classe e escala utilizada;

t) Para análise do produto como um todo, $90 \%$ das linhas testadas devem atender ambas as condições do item f). Sendo satisfeito essa análise o produto é aprovado na classe e escala testada, caso contrário o produto é reprovado. Assim deve-se retornar ao item 6 e testar uma classe inferior, caso não haja classificação nas classes disponíveis, deve-se testar uma escala menor.

No entanto, utilizando a Eq. (5) verifica-se inconsistência do resultado na aplicação do método proposto por Ramirez e Ali (2003), pois retorna sempre um valor constante independentemente do valor do raio. Sabendo-se que o raio do círculo reflete a variabilidade das discrepâncias, o mesmo funcionará como fator de escala. Assim, sugere-se utilizar a Eq. (6) para aplicação do Fator Fuzziness permitindo obter medidas de discrepâncias em unidades lineares.

$$
F F=\frac{\text { área em comum }}{\pi r^{2}} \cdot r
$$

O método do Fator Fuzziness apresenta como limitação o mesmo problema do método dos Pontos Finais, ou seja, analisa apenas os extremos das feições lineares como ilustrado na Figura 1.

\subsection{Método de Influência do Vértice}

O método de Mozas e Ariza (2011) baseia-se na obtenção da distância euclidiana a partir dos vértices da linha de referência $\left(\mathrm{L}_{\mathrm{R}}\right)$ para a linha teste $\left(\mathrm{L}_{\mathrm{T}}\right)$. Estas distâncias são ponderadas em função do comprimento dos segmentos adjacentes ao vértice da $L_{R}$ (Figura 6). Assim, obtém-se o valor ponderado das distâncias entre os vértices de referência para a linha teste. Segundo os mesmos autores:

- Essas distâncias determinam os vetores de discrepância entre as duas linhas;

- O vetor de discrepância médio para a linha a ser controlada é analisado mediante todos os vetores obtidos através dos vértices, ponderando o comprimento de segmentos adjacentes a um determinado vértice; $\mathrm{e}$

- Os deslocamentos dos vértices perto de segmentos mais longos terão mais influência no valor médio de deslocamento.

Figura 6 - Método da Influência do Vértice.

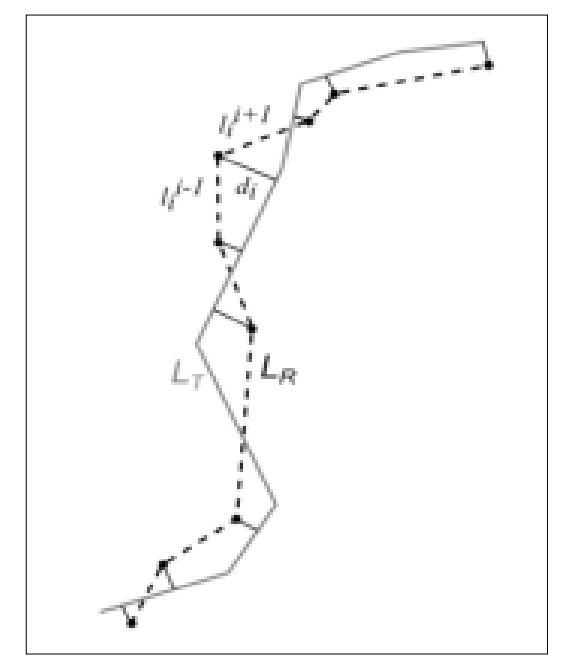

Fonte: Adaptado de Mozas e Ariza (2011, p. 1684).

Segundo Santos et al. (2015), para a aplicação do método da Influência do Vértice, utilizando o padrão de acurácia posicional brasileiro, utilizam-se as seguintes etapas:

a) Selecionar uma amostra de n linhas homólogas de teste $\left(L_{T}\right)$ e de referência $\left(L_{R}\right)$; 
b) Calcular o comprimento $\left(\mathrm{CL}_{\mathrm{R}}\right)$ e extrair os vértices de cada linha de referência;

c) Calcular a menor distância $\left(\mathrm{dh}_{\mathrm{k}}\right)$ para cada vértice $\mathrm{k}$ da linha referência em relação a qualquer segmento da linha teste.

d) Obter os valores dos comprimentos dos segmentos de retas anteriores $\left(\mathrm{l}_{\mathrm{k}-1}\right)$ e posteriores $\left(l_{k+1}\right)$ aos vértices $k$ da linha i de referência;

e) Calcular a discrepância média $\left(D_{\mathrm{i}}\right)$ para cada linha i de referência baseado na Eq. (7);

f) Para o dado espacial ser classificado de acordo com o Decreto $\mathrm{n}^{\circ} 89.817$, verifica-se se $90 \%$ de $D_{i}$ tem que ser menor ou igual que o valor do PEC e o RMS de $D_{i}$ tem que ser menor ou igual ao valor do EP, para a classe e escala empregadas no processo de avaliação da acurácia posicional.

$$
D_{i}=\frac{\left[\sum_{k=1}^{m}\left(d h_{k} \cdot\left(l_{k}^{k-1}+l_{k}^{k+1}\right)\right)\right]_{i}}{2 C L_{R i}}
$$

sendo:

$m$ : Número de vértices da linha de referência;

$d h_{k}$ : Distância horizontal mínima entre o vértice $k$ da linha da referência para linha teste;

$l_{k-1}$ e $l_{k+1}$ : Comprimento dos segmentos adjacentes ao vértice $k$ na $\mathrm{L}_{\mathrm{R}}$;

$C_{L R}$ : Comprimento da feição linear de referência;

$D_{i}$ : Discrepância média.

O método da influência do vértice consiste na medida de distância dos vértices da linha de referência para a linha teste, sendo essas distâncias ponderadas em função do comprimento dos segmentos adjacentes ao vértice analisado.

\subsection{Normalização do Buffer Duplo}

Para Tveite e Langaas (1999), o método do Buffer Duplo deve ser realizado de forma iterativa, visto que é necessário obter a largura do buffer ideal para o conjunto de dados avaliado. Para cada iteração aumentase a largura do buffer até que o resultado se estabilize. Assim, Cruz et al. (2018) realizaram a comparação do método de normalização do Buffer Duplo para definição da largura ideal a ser considerada em cada par de linha em análise com o emprego da largura ideal ao valor do PEC, estabelecido pelo Decreto $\mathrm{n}^{\circ} 89.817$ de acordo com a classe e escala na qual o produto foi avaliado. Foram analisadas feições de hidrografia referente ao município de Tangará da Serra, na região do Pantanal Mato Grossense. O resultado obtido foi variação nas larguras adotadas, no entanto, em ambas as metodologias o produto foi considerado classe $\mathrm{C}$ para escala 1:500.000.

Em Fonseca (2018), analisou-se o comportamento de cada par de linhas homólogas, por meio da normalização dos volumes obtidos, o que permitiu estimar valores de discrepância 3D para cada largura de buffer aplicada na avaliação da acurácia posicional tridimensional. As análises realizadas neste método podem ser separadas seguindo os passos abaixo:

a) Executar a operação de buffer com largura $\mathrm{x}$, nas linhas teste e referência, obtendo assim os polígonos de teste $\left(L_{T}\right)$ e de referência $\left(L_{R}\right)$.

b) Realizar uma operação de sobreposição (overlay) entre os polígonos $L_{T}$ e $L_{R}$, podendo formar quatro diferentes áreas, sendo:

c) Área tipo a. Área não contida em ambos os polígonos $L_{T}$ e $L_{R}$.

d) Área tipo b. Área não contida em $L_{T}$ e contida em $L_{R}$.

e) Área tipo c. Área contida em $L_{T}$ e não contida em $L_{R}$.

f) Área tipo d. Área resultante da interseção entre $L_{T}$ e $L_{R}$.

g) Cálculo da discrepância posicional entre as feições lineares.

Serão analisadas as áreas do tipo b, c e d normalizadas (Figura 7). A normalização é realizada por meio da divisão de cada área pelo valor da área formada da união entre as áreas do buffer de referência e teste. Para Tveite e Langaas (1999), no gráfico da normalização das áreas, as curvas formadas pelas áreas do tipo b e c 
podem, ou não, serem coincidentes (está relacionado à diferença entre o comprimento da linha de referência) e sempre cruzam com a curva formada pela curva da área do tipo d. Assim os valores da largura de buffer para os pontos de cruzamento entre as curvas do gráfico podem ser utilizados como a largura ótima de buffer em um conjunto de dados.

Figura 7- Normalização das áreas obtidas por meio da sobreposição dos buffers.

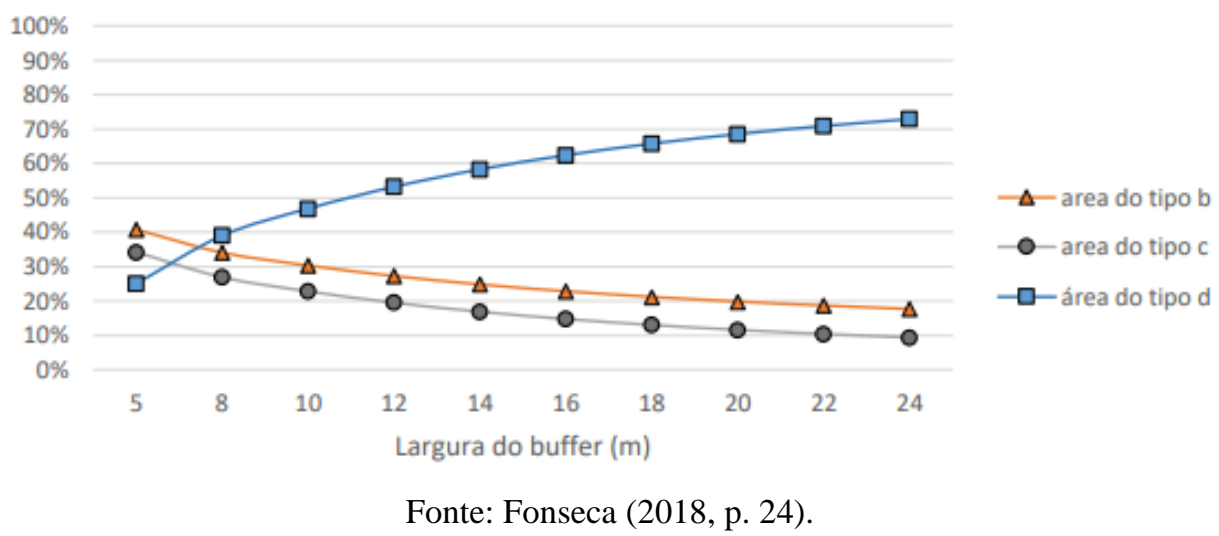

De acordo com Tveite e Langaas (1999) ao aplicar um buffer na linha teste e na linha de referência, tem-se uma ponderação das incertezas, podendo obter uma medida de discrepância média de acordo com a Eq. (8). Para a aplicação do Decreto ${ }^{\circ}$ 89.817, sugere-se verificar se pelo menos $90 \%$ das discrepâncias apresenta valor menor ou igual ao valor do PEC, bem como o RMS da amostra de discrepâncias ser menor ou igual ao valor de EP, para a classe e escala utilizada.

$$
D=\pi \cdot m \frac{\sum(A F)_{i}}{\text { Área }\left(L_{T}\right)}
$$

sendo:

$\sum(A F)_{i}$ : Somatório da área do buffer da linha de referência $\left(L_{R}\right)$ que não coincida com o buffer da linha teste $\left(L_{T}\right)$.

Área $\left(L_{T}\right)$ : Área total do buffer da linha teste $\left(L_{T}\right)$.

m: Largura do buffer.

\section{EXPERIMENTOS E RESULTADOS}

São apresentados a seguir o delineamento da área de estudo, a metodologia e os materiais utilizados no desenvolvido deste trabalho bem como e os resultados e análises do estudo.

\section{1 Área de estudo}

A área de estudo compreende uma região do município de Viçosa no estado de Minas Gerais (Figura 8) e possui uma área de aproximadamente 144 ha. A área de estudo foi escolhida devido à disponibilidade de dados referentes a essa região. 
Figura 8- Localização das feições lineares (em vermelho) utilizadas no processo de avaliação da acurácia posicional do

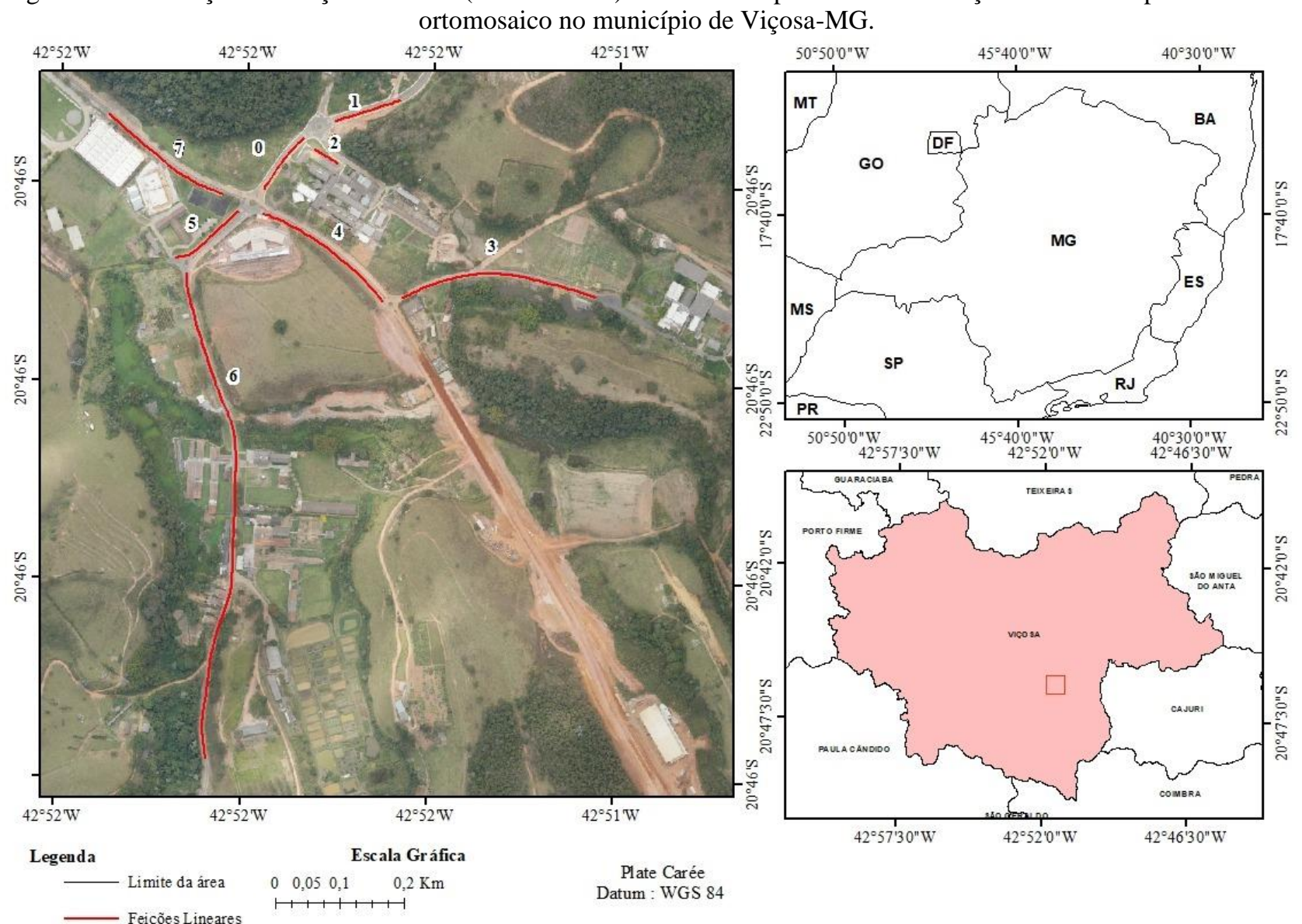

Fonte: Os autores (2021).

\subsection{Material e Métodos}

No presente estudo foram utilizadas imagens do Vant Echar 20A fabricado pela XMOBOTS. O equipamento é composto por uma aeronave, uma estação de controle e um terminal de dados. A estação de controle e o terminal de dados possibilitam o monitoramento da aeronave, que possui um receptor GNSS e o sistema de medição inercial (Inertial Measurement Unit - IMU), fornecendo os dados de atitude do sensor. Para aquisição das imagens foi utilizada uma câmara Sony ILCE-7R com distância focal de 45mm, sobrevoando a área com uma altura média de aproximadamente $467 \mathrm{~m}$ e com sobreposição lateral $60 \%$ e longitudinal de $70 \%$.O processamento das imagens foi realizado de forma automática utilizando 15 pontos de controle distribuídos por toda a área de estudo, com o software fotogramétrico Agisoft PhotoScan 1.2.5, gerando um ortomosaico com resolução espacial de $5 \mathrm{~cm}$. Ressalta-se que o voo foi executado no ano de 2015 .

Para a aplicação e comparação dos métodos de avaliação da acurácia posicional baseados no uso de feições lineares, avaliou-se a acurácia posicional planimétrica do ortomosaico gerado. Aplicaram-se os métodos de feição linear: Pontos Finais, Pontos Intermediários, Ponto Gerado, Influência do Vértice, normalização do Buffer Duplo e Fator Fuzziness, de acordo com a metodologia da seção 2.

Sobre o ortomosaico a ser avaliado, foram selecionados 8 trechos de feições lineares (vias) conforme ilustrado na Figura 8. O levantamento das feições em campo ocorreu no ano de 2015, utilizando os receptores GNSS da marca JAVAD modelo Triumph-1, tendo como método e aquisição o posicionamento relativo estático e NTRIP (Networked Transport of RTCM via Internet Protocol), e conjunto com as informações da estação RBMC VICO (Viçosa-MG). O processamento dos dados de campo foi realizado empregando o Software Topcon Tools 7.5.1 configurado ao sistema de projeção UTM - Fuso 23 S, SIRGAS 2000. Os pontos coletados tiveram precisões posicionais melhores que $4,9 \mathrm{~cm}$.

Por meio da amostra de feições lineares de referência de campo e seus homólogos no ortomosaico, foi possível aplicar os métodos propostos de avaliação da acurácia posicional planimétrica, obtendo as 
discrepâncias posicionais, detectar possíveis outliers, bem como classificar tais dados quanto ao padrão de acurácia posicional definido pelo Decreto 89.817. Nero (2005) sugere que, para a classe A do Decreto 89.817 da escala testada, utilizar o limite de $3 * \mathrm{EP}$ para detectar possíveis outliers.

\subsection{Resultados e análises}

Os experimentos foram divididos em 3 grupos através do agrupamento dos métodos que são similares. No grupo 1, foi utilizado apenas o método da Normalização do Buffer Duplo (NBD) devido basear na geração de buffers. No grupo 2, foram agrupados os métodos de Influência do Vértice (IV), Ponto gerado (PG) e Pontos Intermediários (PI) por tratarem da análise dos pontos pertencentes aos segmentos da linha. E no grupo 3, foram analisados os métodos que utilizam os vértices finais das linhas que são os métodos dos Pontos Finais (PF) e o método do Fator de Fuziness (FF).

Para o método da normatização do buffer duplo, foi necessário encontrar o valor de largura de buffer correspondente para cada par de linhas, uma vez que as linhas contêm discrepâncias diferentes e devem ser analisadas separadamente. Assim, aplicaram-se diferentes larguras de buffer para cada par de linhas analisado. No total, realizaram-se dez iterações, com valores de buffer variando de 0,0015 m até $1 \mathrm{~m}$. Após este procedimento, realizou-se a normalização onde possibilitou obter a largura ideal do buffer para cada par de linhas analisado. A Figura 9 mostra os resultados da normalização para cada par de linhas avaliadas.

Figura 9 - Normalização do buffer duplo das linhas teste e referência para o conjunto de dados testado.

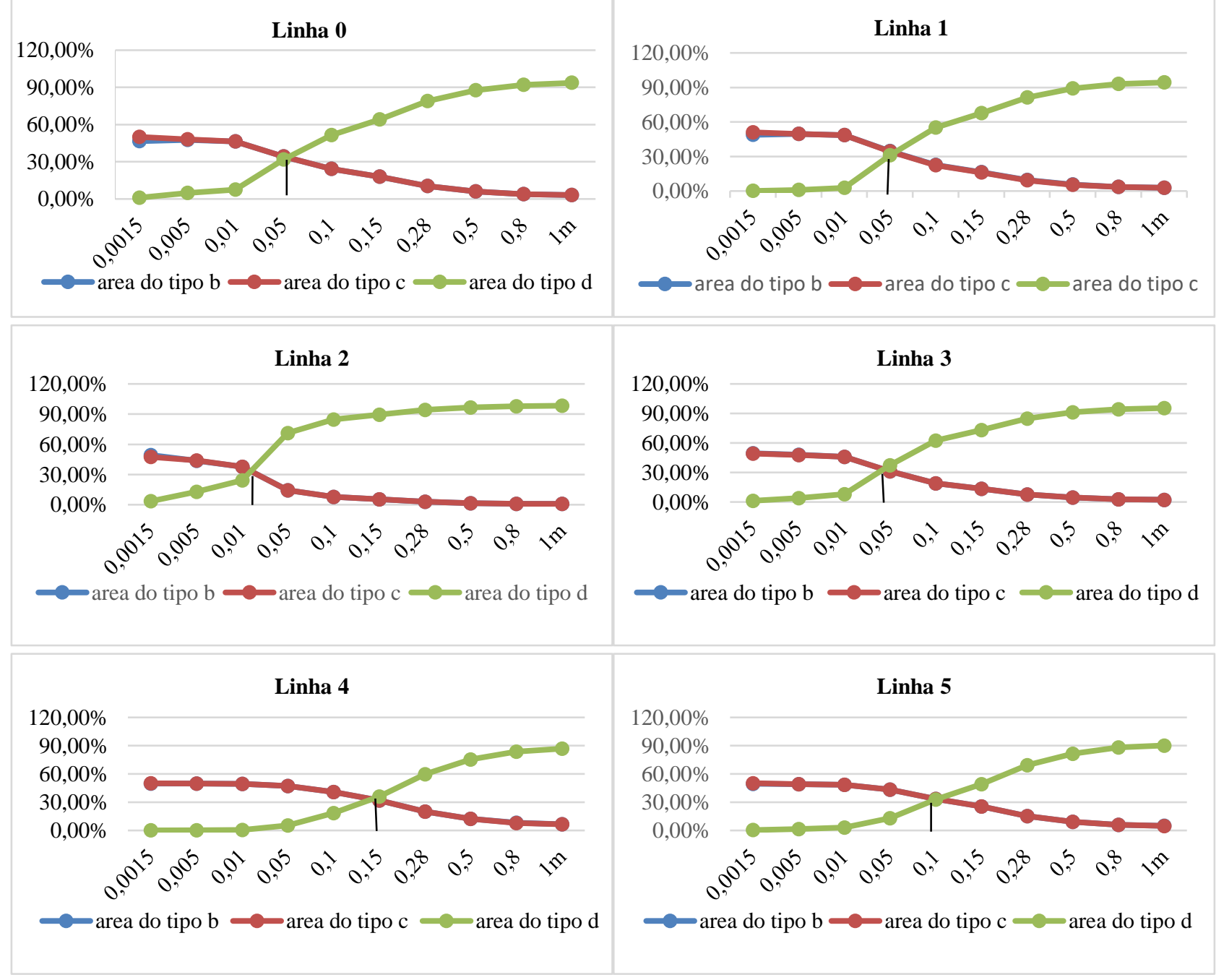




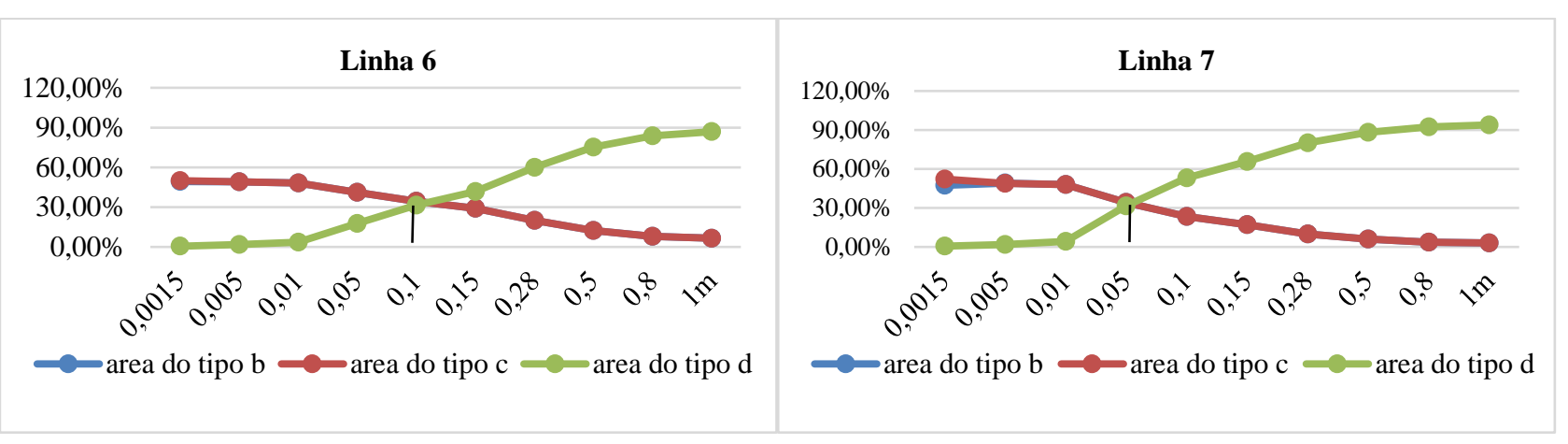

Fonte: Os autores (2021).

De acordo com a Figura 9, observa-se que para cada par de linhas homólogas, a estimação para o ponto de interseção ocorre em diferentes larguras de buffer. Por exemplo, o ponto de interseção na linha 0 (zero) ocorre para uma largura de buffer de aproximadamente $0,06 \mathrm{~m}$, enquanto na linha 4 ocorre na largura de aproximadamente $0,14 \mathrm{~m}$. A Tabela 2 mostra os valores de discrepância posicional obtidos pela Eq. (8), aplicando para cada linha a largura do buffer encontrado pelo processo de normalização das áreas. Verifica-se que as linhas 4, 5 e 6 apresentaram maiores valores de discrepâncias.

Tabela 2- Discrepâncias posicionais para o conjunto de linhas de estudo, segundo Eq. (8).

\begin{tabular}{c|c|c}
\hline ID & Largura obtida na NBD (m) & Discrepância Posicional (m) \\
\hline linha0 & 0,06 & 0,09 \\
\hline linha1 & 0,06 & 0,09 \\
\hline linha2 & 0,02 & 0,03 \\
\hline linha3 & 0,04 & 0,07 \\
\hline linha4 & 0,14 & 0,22 \\
\hline linha5 & 0,1 & 0,16 \\
\hline linha6 & 0,11 & 0,17 \\
\hline linha7 & 0,06 & 0,09 \\
\hline
\end{tabular}

Fonte: Os autores (2021).

Assim, de posse das amostras de discrepâncias, foram verificados possíveis outliers pelo método de

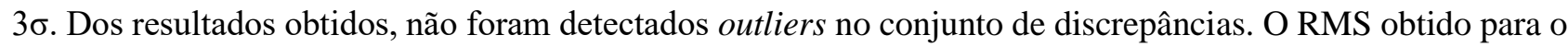
conjunto da amostra foi de $0,14 \mathrm{~m}$.

No grupo 2, a análise do método de Influência do Vértice (IV) como descrito no item 2.5 baseia-se na obtenção da distância euclidiana a partir dos vértices da linha de referência $\left(L_{R}\right)$ em relação a linha teste. A Figura 10 apresenta as discrepâncias das 8 linhas de estudo, onde pode-se verificar que a linha 4 apresentou a maior discrepância (equivalente a $0,18 \mathrm{~m}$ ) entre todas as linhas analisadas. Ressalta-se que foram verificados possíveis outliers com uso do método de $3 \sigma$, e não foram detectados outliers na amostra de estudo. O RMS obtido para o conjunto da amostra foi de $0,09 \mathrm{~m}$.

Figura 10 - Gráfico das discrepâncias utilizando o método de Influência do Vértice (IV).

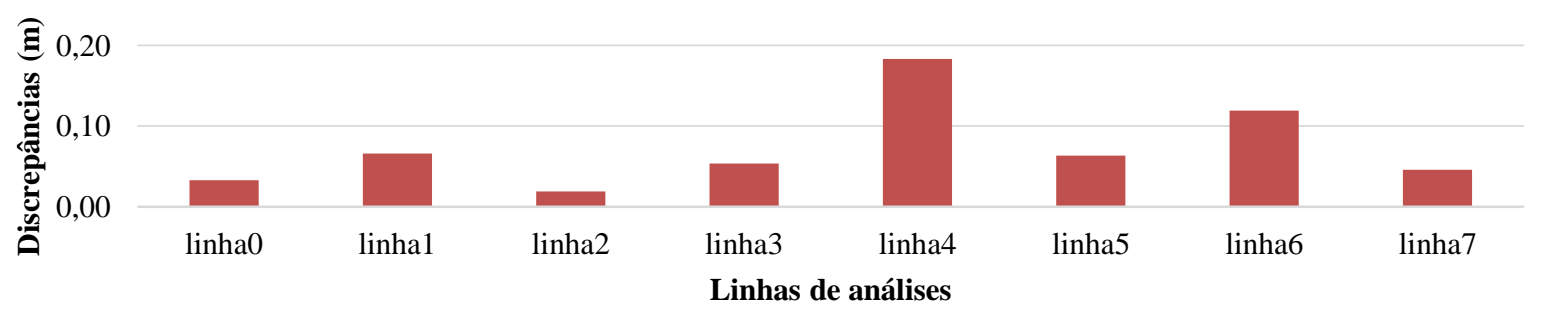

Fonte: Os autores (2021).

Para análise dos métodos do Ponto Gerado e Pontos Intermediários foi aplicado o espaçamento $\varepsilon$ igual a 0,2m para escala de 1:1.000. Contudo, em ambos os casos a análise para classe A falhou devido aos resultados não atenderem às exigências propostas nas seções 2.2 e 2.3. Assim, a análise foi realizada mediante as 
especificações para Classe B, ou seja, foi analisado se o conjunto de discrepâncias de cada linha em análise apresenta valor menor ou igual a 0,5m (valor do PEC para classe B), bem como o RMS de cada linha seja menor ou igual ao valor de $0,30 \mathrm{~m}$ (valor do EP para classe B). Além disso, foi aplicado o método do $3 \sigma$ para detecção de outliers e os resultados obtidos não indicaram erros grosseiros no conjunto de discrepâncias. A Tabela 3 apresenta os resultados da análise do método do Ponto Gerado e do método dos Pontos intermediários para cada linha da área de estudo.

Tabela 3 - Resultados obtidos da análise dos métodos do Ponto Gerado e Pontos Intermediários para o espaçamento $\varepsilon$ igual a $0,2 \mathrm{~m}$.

\begin{tabular}{c|c|c|c|c}
\hline \multirow{2}{*}{ Feição linear } & \multicolumn{2}{|c|}{ Ponto Gerado } & \multicolumn{2}{c}{ Pontos Intermediários } \\
\cline { 2 - 5 } & $\% \leq$ PEC $(0,5 \mathrm{~m})$ & RMS $(\mathrm{m})$ & $\% \leq$ PEC $(0,5 \mathrm{~m})$ & RMS $(\mathrm{m})$ \\
\hline linha0 & 100 & 0,09 & 100 & 0,09 \\
\hline linha1 & 100 & 0,07 & 100 & 0,07 \\
\hline linha2 & 100 & 0,02 & 100 & 0,02 \\
\hline linha3 & 100 & 0,03 & 100 & 0,03 \\
\hline linha4 & 100 & 0,11 & 100 & 0,12 \\
\hline linha5 & 100 & 0,12 & 100 & 0,12 \\
\hline linha6 & 96,95 & 0,05 & 96,90 & 0,05 \\
\hline linha7 & 100 & 0,07 & 100 & 0,07 \\
\hline
\end{tabular}

Fonte: Os autores (2021).

Verifica-se por meio da Tabela 3, que os métodos do Ponto Gerado e dos Pontos intermediários apresentaram valores similares em cada feição linear, com destaque para a linha 6 que em ambos os métodos apresentou maior valor de RMS e equivalente a $0,20 \mathrm{~m}$.

Diante dos resultados encontrados no grupo 2, pode-se verificar que o método do ponto gerado foi similar ao método dos pontos intermediários, visto que é realizada a análise de pontos em toda a feição linear. Já para o método de influência de vértice a avaliação é realizada mediante os pontos dos vértices da linha de referência, podendo gerar resultados que fiquem abaixo do esperado.

Para análise do grupo 3, aplicaram as metodologias propostas nas seções 2.1 e 2.4 para os métodos do Fator de Fuziness e Pontos Finais, respectivamente ou seja, foi analisado se o conjunto de discrepâncias de cada linha em análise apresenta valor menor ou igual a 0,28m (valor do PEC para classe A), bem como o RMS de cada linha seja menor ou igual ao valor de $0,17 \mathrm{~m}$ (valor do EP para classe A). Ressalta-se que o conjunto de discrepância não apresentou outliers pelo método do $3 \sigma$. A Tabela 4 apresenta os resultados da análise em cada linha.

Tabela 4 - Resultados obtidos da análise dos métodos do Fator de Fuziness e Pontos Finais de acordo com as tolerâncias do Decreto $n^{\circ} 89.817$.

\begin{tabular}{c|c|c|c|c}
\hline \multirow{2}{*}{ Feição Linear } & \multicolumn{2}{|c|}{ Fator de Fuziness } & \multicolumn{2}{c}{ Pontos Finais } \\
\cline { 2 - 5 } & $\begin{array}{c}\% \leq \text { PEC } \\
(0,28 \mathrm{~m})\end{array}$ & $\begin{array}{c}\text { RMS (m) } \\
(0,17 \mathrm{~m})\end{array}$ & $\begin{array}{c}\text { \% PEC } \\
(0,28 \mathrm{~m})\end{array}$ & $\begin{array}{c}\text { RMS (m) } \\
(0,17 \mathrm{~m})\end{array}$ \\
\hline linha0 & 100 & 0,04 & 100 & 0,08 \\
\hline linha1 & 100 & 0,03 & 100 & 0,10 \\
\hline linha2 & 100 & 0,03 & 100 & 0,01 \\
\hline linha3 & 100 & 0,06 & 100 & 0,09 \\
\hline linha4 & 100 & 0,00 & 100 & 0,12 \\
\hline linha5 & 100 & 0,05 & 100 & 0,06 \\
\hline linha6 & 100 & 0,04 & 100 & 0,16 \\
\hline
\end{tabular}

Fonte: Os autores (2021).

Os métodos do Fator de Fuziness e o método dos Pontos Finais apresentam metodologias diferentes para o cálculo das discrepâncias. Através da Tabela 4, verifica-se que no método do Fator de Fuziness os resultados apresentaram valores menores em relação ao método dos pontos finais. Ambos os métodos apresentaram maiores valores de RMS na linha 7 de 0,07m no método Fator de Fuziness e 0,17m no método dos Pontos Finais. 
Na aplicação do método do Ponto Gerado (PG), Ponto Intermediário (PI), Fator de Fuziness (FF) e Pontos Finais (PF) como descrito nas seções 2.1, 2.2, 2.3 e 2.4, para avaliação da acurácia posicional, verificase que pelo menos $90 \%$ do conjunto de discrepâncias de cada linha apresentam valores menores ou iguais ao valor do PEC, bem como o RMS da amostra de discrepâncias de cada linha ser menor ou igual ao valor de EP, para a classe e escala utilizada. Em seguida é avaliado se $90 \%$ do conjunto de linhas atendem aos dois critérios simultaneamente. Como resultados da aplicação dos métodos de feições lineares de acordo com Decreto $\mathrm{n}^{\circ}$ 89.81789.817/ET-CQDG, tem-se a Tabela 5 apresentando a classe e escala testada no estudo.

Tabela 5 - Classificação da acurácia posicional do ortomosaico, utilizando métodos de feição linear de acordo com Decreto ${ }^{\circ}$ 89.81789.817/ET-CQDG, para a escala 1:1.000.

\begin{tabular}{c|c|c|c|c|c|c}
\hline Método de Feição Linear & PF & PI & PG & IV & FF & NBD \\
\hline $\begin{array}{c}\text { Classe - PEC-PCD } \\
1: 1.000\end{array}$ & CLASSE A & CLASSE B & CLASSE B & CLASSE A & CLASSE A & $\begin{array}{c}\text { CLASSE } \\
\text { A }\end{array}$ \\
\hline
\end{tabular}

Fonte: Os autores (2021).

Verifica-se pela Tabela 5 que os métodos Pontos Finais, Influência de Vértice e Fator Fuzziness apresentaram os mesmos resultados, enquadrando-se na Classe A para escala de 1:1.000. Para o método de normalização do Buffer Duplo foi aplicado o Decreto ${ }^{\circ} 89.817$ verificando que $90 \%$ das discrepâncias apresentaram valores menores ao valor do $0,28 \mathrm{~m}$, bem como o RMS da amostra de discrepâncias apresentou valor menor ao PEC. Assim, o método de normalização do Buffer Duplo enquadrou-se também na Classe A para escala de 1:1.000. Já os métodos do Ponto Gerado e Pontos intermediários enquadram-se na Classe B para escala de 1:1.000.

Analisando o conjunto de linhas, verifica-se que nos métodos de normalização do Buffer Duplo, Influência de Vértice, Ponto Gerado e Pontos intermediários obtiveram maiores valores de discrepâncias nas linhas 4, 5 e 6. Os métodos normalização do Buffer duplo e Influência de Vértice obtêm um valor de discrepância média baseado nas diferenças entre as linhas homólogas ou entre os vértices das mesmas. Desta forma, pode-se ter uma linha que apresente uma discrepância média de valor razoável, mas que em algum trecho de seu segmento, apresente uma discrepância significativa.

No método Ponto Gerado e Pontos intermediários, caso exista algum ponto com valor alto de discrepância, este poderá influenciar as estatísticas da amostra de checagem, mostrando que o produto apresenta alguma inconsistência.

Diante dos resultados encontrados, verifica-se também que os métodos dos grupos 1 e 2 apresentam valores similares de discrepância, embora o método de Influência de Vértice apresente valores de discrepância ligeiramente inferiores aos demais. Isso pode ser decorrente do fato da análise do método de Influência do Vértices avaliar apenas os vértices existentes da linha de referência. Em se tratando dos métodos aplicados no grupo 3 é notório que os valores das discrepâncias foram inferiores devido ao fato métodos avaliarem apenas as extremidades das linhas.

\section{CONCLUSÃO}

Os métodos utilizados neste trabalho são relativamente de simples implementação em um ambiente de Sistema de Informações Geográficas, sendo mais uma alternativa para o Controle de Qualidade de bases cartográficas. De um modo geral, os resultados da avaliação do ortomosaico apresentaram Classe A para a escala de 1:1.000 quanto ao Decreto ${ }^{\circ}$ 89.817 / ET-CQDG na aplicação dos métodos Pontos Finais, Influência de Vértice, Fator Fuzziness e pelo método de normalização do Buffer Duplo. Já os métodos do Ponto Gerado e Pontos Intermediários apresentaram classificação B para a escala 1:1.000.

Os métodos de feições lineares Pontos Intermediários e Ponto Gerado obtém o valor da discrepância baseado em pontos separados com espaçamento $(\varepsilon)$ pré-estabelecido no valor do PEC para a escala e a classe utilizada no processo de avaliação. Assim, quanto maior a escala, menor o espaçamento $(\varepsilon)$ entre os pontos. No entanto, quanto menor as escalas menos restritivas se tornam os métodos. Verifica-se também que no método do Ponto Gerado a metodologia funciona adequadamente quando não estão presentes distorções geométricas significativas entre as feições lineares, ou seja, para os segmentos lineares que apresentam 
distâncias similares.

Apesar dos métodos do Ponto Gerado e Pontos Intermediários apresentarem classificação B para a escala 1:1.000, ambos podem ser ponderados como os métodos mais eficazes, devido ao fato de gerar um conjunto de discrepâncias em todo o segmento da linha analisada, as quais pode-se investigar a presença de tendências nos dados.

No método de normalização do buffer, os resultados mostram que ao realizar iterações, variando-se a largura do buffer, é possível inferir no comportamento da linha teste em relação à linha de referência e obter medidas como a largura ideal para se calcular discrepâncias por meio do método do buffer duplo.

No método da influência do vértice, pode-se verificar que o método realiza análise mediante os pontos dos vértices das linhas de referência podendo gerar conclusões que fiquem aquém do esperado quando as quantidades dos vértices não são representativas em toda a linha de referência. Observa-se que a quantidade e distribuição de vértices na linha de referência influência diretamente na avaliação de tendência.

Apesar dos métodos Fator Fuzziness (adaptação) e o método dos Pontos Finais apresentarem Classe A ambos consideram a discrepância apenas nos extremos das linhas, não levando em consideração o comportamento da feição linear. Tendo em vista a comparação dos métodos tendo por base o padrão de acurácia posicional brasileiro, definido pelo Decreto $n^{\circ}$ 89.817/ ET-CQDG verifica-se que os métodos do Ponto Gerado e Pontos Intermediários apresentaram, neste estudo, melhores desempenhos quando comparados aos métodos de Influência do Vértice e Normalização do Buffer Duplo, sendo os mesmos avaliados mediante a comprimentos similares de feições lineares (linhas testes e linhas de referência).

É importante ressaltar que nos casos onde feições lineares apresentam diferentes comprimentos ocorrerá inconsistência na aplicação dos métodos. Sugere-se como trabalhos futuros avaliar a influência de diferentes espaçamentos $\varepsilon$ na aplicação dos métodos Pontos Intermediários e Ponto Gerado para análise do Controle de Qualidade de bases cartográficas.

Por fim, verifica-se que os métodos apresentados são baseados na análise de pontos no decorrer da feição linear, assim recomenda-se a análise de outras propriedades geométricas nas feições lineares em trabalhos futuros. Recomenda-se também devido ao fato de os métodos gerarem análise de medidas de discrepâncias, investigar a presença de tendências nos dados.

\section{Contribuição dos Autores}

Todos os autores tiveram contribuições essenciais para elaboração deste artigo. Conceptualização, Curadoria dos dados, Análise formal, Investigação, Metodologia, Recursos, Software, Supervisão, Validação, Redação (revisão e edição) teve colaboração de todos os autores. A Redação (minuta inicial) teve participação principal do primeiro autor e a Administração do projeto teve participação principal do segundo autor.

\section{Conflitos de Interesse}

Os autores declaram que não há conflito de interesse.

\section{Referências}

ARIZA, F.J. Calidad en la Producción Cartográfica, $1^{\text {a }}$ ed., Madrid: RA-MA, 2002

ARIZA, F.J., ATKINSON, A.D. Analysis of Some Positional Accuracy Assessment Methodologies. Journal of Surveying Engineering, v.134, n.2, p. 45-54, 2008.

BLAKEMORE, M Generalization and Error in Spatial Databases. In: Cartographica, v. 21, 131-139, 1984.

BURITY, E. F. A carta cadastral urbana - Seleção de dados a partir da análise das necessidades dos usuários. 1999. 106p. Dissertação (Mestrado em Engenharia Cartográfica) - IME. Rio de Janeiro, Brasil, 1999.

CRUZ, D. T.; SILVA, P. L.; FONSECA, I. G. R.; SANTOS, A. P. Comparação de metodologias na aplicação do método buffer duplo para análise de acurácia posicional por feições lineares. In: SIMPÓSIO 
BRASILEIRO DE CIÊNCIAS GEODÉSICAS E TECNOLOGIAS DA GEOINFORMAÇÃO, VII, 2018, Recife, Brasil. Anais... Recife, Brasil: UFPE, 2018, p. 196-204.

DAL POZ, A. P.; GALO, M.; FERREIRA, F. M. Metodologias para a avaliação geométrica de feições cartográficas, In: COLÓQUIO BRASILEIRO DE CIÊNCIAS GEODÉSICAS, II, 2001. Curitiba, Brasil: UFPR, 2001. CD-ROM.

FERREIRA, L. F.; CINTRA, J. P. Quantificação de discrepâncias entre feições lineares por retângulos equivalentes. Revista Brasileira de Cartografia, v. 51, p. 1-8, 1999.

FONSECA, I. G. R. DA. Avaliação da acurácia posicional tridimensional utilizando feições lineares.2018. 84p. Dissertação de Mestrado em Engenharia Civil. UFV. Viçosa, Brasil, 2018.

GALO, M.; POZ, A. P. D.; FERREIRA, F. M. O Uso De Feições No Controle De Qualidade Em Cartografia. In: CONGRESSO BRASILEIRO DE CARTOGRAFIA, XIX. Porto Alegre, Brasil. 2001.

GIORDANO, A.; VEREGIN, H. Il controllo di qualità nei sistemi informativi territorial. Come valutare e mantenere l'accuratezza del database, Venezia, Il Cardo, p. 138, 1994.

GOODCHILD, M. F.; HUNTER, G. J. A simple positional accuracy measure for linear features. International Journal of Geographical Information Science, v. 11, n. 3, p. 299-306, 1997.

GOODCHILD, M. F. Principles of Modeling Uncertainties in Spatial Data and Spatial Analyses. $1^{\mathrm{a}}$ ed. Boca Raton, FL: CRC Press, 2010.

HEIPKE, C; MAYER, H.; WIEDEMANN, C.; JAMET, O. Evaluation of Automatic Road Extraction. In: INTERNATIONAL ARCHIVES OF PHOTOGRAMMETRY AND REMOTE SENSING. Stuttgart, Alemanha. 1997. 3D Reconstruction and Modelling of Topographic Objects. 1997. p. 47-56.

ISO 19157:2013: Geographic information: data quality. Geneva: ISO, p.146, 2013.

KAGAWA, Y.; SEKIMOTO, Y.; SHIBASKI, R. Comparative study of positional accuracy evaluation of line data. Proceedings of the ACRS, 1999.

LUGNANI, J. B. Using digital entities as control. 1998. 159p. Dissertação de Doutorado. The University of New Brunswick (UNB), Canada, 1980.

LUGNANI, J.B. Estimativa de Qualidade de Feições Digitalizadas: Um Novo Método. Revista Brasileira de Cartografia, v. 39, p. 26-29, 1986.

MASRY, S. E.; GAUTHIER, J. R. R.; LEE, Y. C. Accuracy and time comparisons of digital maps. 14TH CONGRESS OF THE INTERNATIONAL SOCIETY OF PHOTOGRAMMETRY, Hamburg, 1980.

MCMASTER, R.B. A statistical analysis of mathematical measures for linear simplification. The American Cartographer, v.13, n. 2, p. 103-116, 1986.

MOZAS, A. T. C. Control de La Calidad Posicional En Cartografia Por Elementos Lineales. 2007. 249p. Dissertação de Doutorado. Universidad de Jaén, Spain, 2007.

MOZAS, A. T.; ARIZA F. J. Methodology for Positional Quality Control in Cartography Using Linear Features. The Cartographic Journal, v. 47, n. 4, p. 371-378, 2010.

MOZAS, A. T.; ARIZA F. J. New Method for Positional Quality Control in Cartography Based on Lines. A Comparative Study of Methodologies. International Journal of Geographical Information Science, v. 25, n. 10, p. 1681-95, 2011.

NERO, M. A. Proposta para Controle de qualidade de bases cartográficas com ênfase na componente posicional. 2005. 186p. Dissertação (Doutorado) - Escola Politécnica da USP, Brasil, 2005.

NOGUEIRA JR., J. B. Controle de qualidade de produtos cartográficos: uma proposta metodológica. 2003. 147p. Dissertação de Mestrado em Engenharia Cartográfica. UNESP. Presidente Prudente, Brasil, 2003.

PEREIRA, T. A. J., NERO, M. A. Análises de Normas de Controle de Qualidade Cartográfica Ao Redor Do Mundo: Exemplos Atuais de Alguns Países. In: SIMPÓSIO BRASILEIRO DE CIÊNCIAS GEODÉSICAS E TECNOLOGIAS DA GEOINFORMAÇÃO, IV, 2012, Recife, Brasil. Anais... Recife, Brazil: UFPE, 2012. p.01-010. 
RAMIREZ, J.R. ALI, T. Progress in metrics development to measure positional accuracy of spatial data. In: PROCEEDINGS OF THE 21ST INTERNATIONAL CARTOGRAPHIC CONFERENCE (ICC). Durban, South Africa, 2003.

SANTOS, A.P. Avaliação posicional em dados espaciais com o uso da estatística espacial. 2010. 126p. Dissertação de mestrado em Engenharia Civil. UFV. Viçosa, Brasil, 2010.

SANTOS, A. P.; MEDEIROS, N. G.; SANTOS, G. R.; RODRIGUES, D. D. Controle de qualidade posicional em dados espaciais utilizando feições lineares. Boletim de Ciências Geodésicas, v. 21, p. 233-250, 2015.

SANTOS, A. P.; RODRIGUES, D. D.; SANTOS, N. T.; GRIPP JUNIOR, J. Avaliação da acurácia posicional em dados espaciais utilizando técnicas de estatística espacial: proposta de método e exemplo utilizando a norma brasileira. Boletim de Ciências Geodésicas, v. 22, n. 4, p. 630-650, 2016.

SCHDMIDLEY, R. Framework for the Control of Quality in Automated Mapping. 1996. 328p. Dissertação de doutorado em Filosofia, Ohio State University, Geodetic Science and Surveying, Ohio, Estados Unidos, 1996.

SHI, W.; LIU, W. A stochastic process-based model for the positional error of line segments in GIS. International Journal of Geographical Information Science, v. 14, n. 1, p. 51-66, 2000.

SILVA, M. V.; SCHULER, C. A. B. Avaliação de dados planimétricos lidar para áreas urbanas: Recife - PE. RBC. Revista Brasileira de Cartografia, v. 67, p. 1103-1117, 2015.

TVEITE, H.; LANGAAS, S. Accuracy assessments of geographical line data sets, the case of the digital chart of the world. International Journal of Geographical Information Science. p. 145-154, 1995.

TONG, X.; SUN, T.; FANA, J.; GOODCHILD, M. F.; SHI, W. A statistical simulation model for positional error of line features. International Journal of Applied Earth Observation and Geoinformation, v. 21, p. 136-148, 2013.

TVEITE, H.; LANGAAS, S. An accuracy assessment meted for geographical line data sets based on buffering. Int. Journal Geographical Information Science, v. 13, n. 1, p. 27-47, 1999.

VIEIRA, C. A. O., MATHER, P. M. Tecniques for estimating the positional and thematic accuracy of remotely sensed products. In: SIMPÓSIO BRASILEIRO DE SENSORIAMENTO REMOTO, XII, 2005, Goiânia, Brasil. Anais... Goiânia, Brasil: 2005, p. 4351-4359.

\section{Biografia do autor principal}

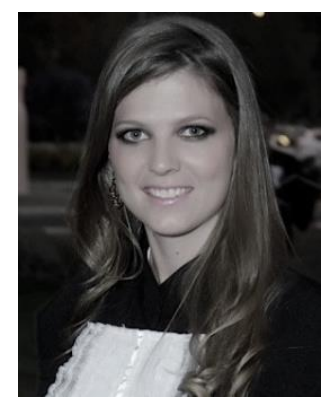

Juliette Zanetti, nasceu em Santa Teresa no estado do Espírito Santo em 1989. Possui graduação em Engenharia de Agrimensura e Cartográfica pela Universidade Federal de Viçosa. Complementação Pedagógica em Física pelo Instituto Federal de Educação, Ciência e Tecnologia do Espírito Santo. Mestre em Engenharia Civil, área de Concentração em Informações Espaciais pela Universidade Federal de Viçosa. Doutorado em andamento em Engenharia Civil, área de Concentração em Informações Espaciais pela Universidade Federal de Viçosa. Pesquisa e publicações tendo principal contribuição no controle de qualidade em produtos cartográficos. 